\title{
Przyczyny pęknięć lutospoin w złączach różnoimiennych typu aluminium - ocynkowana stal niestopowa
}

\author{
Cracking phenomena in dissimilar laser-brazed joints \\ of aluminum and galvanized low carbon steel
}

\section{Streszczenie}

W artykule przedstawiono wyniki badań dotyczących przyczyn pękania lutospoin w różnoimiennych złączach zakładkowych wykonanych laserem diodowym dużej mocy ROFIN DL 020 z użyciem materiału dodatkowego w postaci proszku aluminium, na przykładzie łączenia cienkiej blachy aluminiowej z blachą stalową pokrytą elektrolitycznie powłoką cynkową. Przedstawiono wyniki badań metalograficznych makroskopowych i mikroskopowych. Wskazano na problemy oraz przedstawiono sugestie dotyczące technologii lutospawania laserowego materiałów znacznie różniących się własnościami fizycznymi i składem chemicznym.

Słowa kluczowe: lutospawanie laserowe; laser diodowy dużej mocy; złącza różnoimienne; fazy międzymetaliczne; pękanie kruche; materiały trudnospawalne; aluminium; stal niestopowa ocynkowana elektrolitycznie

\section{Abstract}

A study on cracking phenomena during laser braze weIding of dissimilar lap joints between aluminum thin plate and galvanized low carbon sheet steel is described. The experiments were carried out using a high power diode laser Rofin DL020 and aluminum powder as filler metal. Macro and microstructure analysis of the joints were analysed. Issues and problems in laser braze welding of materials having different chemical composition and physical properties are presented.

Keywords: laser braze welding; high power diode laser; dissimilar joints; intermetallic phase; cracking; difficult to weld materials; aluminium sheet; galvanized low carbon sheet steel

\section{Wstęp}

Rosnące aktualnie wymagania przemysłu motoryzacyjnego, co do odporności na korozję, jak również chęć zapewnienia wysokiej wytrzymałości blach karoseryjnych przy zachowaniu możliwie niskiej masy oraz długiej i bezpiecznej eksploatacji samochodów spowodowały, że regułą stało się wykonywanie większości elementów nadwozi pojazdów z blach stalowych pokrytych galwanicznie powłoką cynko-

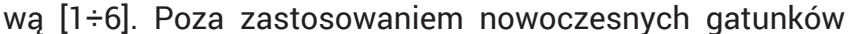
stali typu IF (Interstitial Free), DP (Dual-Phase), TRIP (Transformation-Induced Plasticity), wprowadzono również nowe technologie wykonywania elementów karoserii samochodowych (tailored blank, tailor roled blanks) oraz nowoczesne procesy łączenia materiałów różnoimiennych, np. aluminium ze stalą. Obecnie zgrzewanie punktowe oporowe czy tradycyjne spawanie łukowe metodami MIG/MAG wyparte zostały w znacznym stopniu przez klejenie, procesy niskoenergetycznego lutospawania łukowego elektrodą topliwą w osłonach gazowych takie jak: CMT, ColdArc, STT, CBT, czy spawanie laserowe. Technologie te pozwalają na wykonanie wysokiej jakości połączeń cienkich blach stalowych o grubości $0,3 \div 3,0 \mathrm{~mm}$, bez powłok i z pokryciami ochronnymi o grubości warstwy do $15 \mu \mathrm{m}$, blach aluminiowych o minimalnej grubości wynoszącej 0,4 mm, blach ze stali nierdzewnej, a także łączenie materiałów różnoimiennych przy ograniczo-

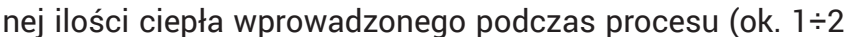

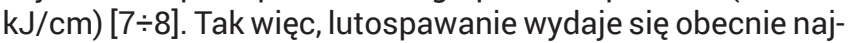
bardziej odpowiednią i perspektywiczną technologią łączenia stalowych elementów pokrytych galwanicznie powłoką cynkową z elementami aluminiowymi. Duże perspektywy w tym zakresie należy wiązać z technologią lutospawania laserowego, szczególnie z wykorzystaniem materiałów dodatkowych o niskim zakresie temperatur likwidusu i solidusu, np. spoiw typu: Zn-Al4 $\left(385 \div 418^{\circ} \mathrm{C}\right)$ lub Al-Si12 $\left(573 \div 585^{\circ} \mathrm{C}\right)$. Ważkim problemem dotyczącym tego typu połączeń są pęknięcia lokalizujące się najczęściej w obszarze materiału lutospoiny, tuż przy powierzchni cynkowej powłoki ochronnej blachy stalowej.

\section{Przebieg i wyniki badań}

Celem badań było określenie możliwości wykonania różnoimiennych złączy zakładkowych w procesie lutospawania laserowego cienkich blach aluminiowych i stali niestopowej obustronnie ocynkowanej elektrolitycznie z zastosowaniem spoiwa w postaci proszku aluminium. Na podstawie badań

Dr inż. Artur Czupryński, dr inż. Damian Janicki - Politechnika Śląska.

Autor korespondencyjny/Corresponding author. artur.czuprynski@polsl.pl 
Tablica I. Dane techniczne lasera diodowego dużej mocy ROFIN DL 020

Table I. Technical data of high power diode laser ROFIN DL 020

\begin{tabular}{|l|c|}
\hline Długość fali promienia laserowego & $808[\mathrm{~nm}] \pm 5[\mathrm{~nm}]$ \\
\hline Moc wyjściowa & $1400[\mathrm{~W}]$ \\
\hline Zakres mocy & $100 \div 2000[\mathrm{~W}]$ \\
\hline Długość ogniska wiązki lasera & $82[\mathrm{~mm}]$ \\
\hline Wymiary ogniska wiązki laserowej & $1,8 \times 6,8[\mathrm{~mm}]$ \\
\hline
\end{tabular}

Tablica II. Skład chemiczny oraz własności mechaniczne ze stali miękkiej niestopowej do bezpośredniej obróbki plastycznej gatunku DC04+ZE75/75 obustronnie ocynkowanej elektrolitycznie (wg PN-EN10152:2011)

Table II. Chemical composition and mechanical properties of double-sided electrogalvanized low-carbon sheet steel DC04+ZE75/75 (according to PN-EN10152:2011)

\begin{tabular}{|c|c|c|c|}
\hline \multicolumn{4}{|c|}{ Skład chemiczny [\%] } \\
\hline$C$ & $M n$ & $P$ & $S$ \\
\hline$<0,08$ & $<0,40$ & $<0,03$ & $<0,03$ \\
\hline \multicolumn{4}{|c|}{ Własności mechaniczne } \\
\hline$R_{e}[\mathrm{MPa}]$ & $\mathrm{R}_{\mathrm{m}}$ min. [MPa] & $\mathrm{A}_{5}$ min. [\%] & $\begin{array}{c}\text { Grubość warstwy cynku, } \\
{[\mu \mathrm{m}]}\end{array}$ \\
\hline $140 \div 220$ & $270 \div 350$ & 38 & 7,5 \\
\hline
\end{tabular}

Tablica III. Skład chemiczny oraz własności mechaniczne blachy z aluminium gatunku 1050A (wg normy PN-EN 573-3:2014) Table III. Chemical composition and mechanical properties of aluminium sheet grade 1050A (according to PN-EN 573-3:2014)

\begin{tabular}{|c|c|c|c|c|c|c|c|c|}
\hline \multicolumn{8}{|c|}{ Skład chemiczny [\%] } \\
\hline $\mathrm{Al}$ & $\mathrm{Fe}$ & $\mathrm{Si}$ & $\mathrm{Zn}$ & $\mathrm{Ti}$ & $\mathrm{Mg}$ & $\mathrm{Mn}$ & $\mathrm{Cu}$ & inne \\
\hline 99,5 & $<0,4$ & $<0,25$ & $<0,07$ & $<0,05$ & $<0,05$ & $<0,05$ & $<0,05$ & $<0,03$ \\
\hline \multicolumn{8}{|c|}{ Własności mechaniczne } \\
\hline \multicolumn{3}{|c|}{$\mathrm{R}_{\mathrm{m}}$ min. [MPa] } & \multicolumn{3}{c|}{$\mathrm{A}_{5}$ min. [\%] } \\
\hline \multicolumn{3}{|c|}{$65 \div 95$} & \multicolumn{3}{c|}{26} \\
\hline
\end{tabular}

wizualnych i metalograficznych ocenie poddane zostały kształt lutospoiny i jakość złączy oraz struktura materiału lutospoiny i materiałów rodzimych.

Próby lutospawania laserowego wykonano na stanowisku zmechanizowanym wyposażonym stół krzyżowy z prowadnicami prostoliniowymi, na którym znajdował się układ mocujący pozwalający na sztywne utwierdzenie lutospawanych blach, laser diodowy dużej mocy ROFIN DL 020, (tablica I), uzbrojony w głowicę ustawioną prostopadle do powierzchni stołu oraz talerzykowy podajnik proszku, podający spoiwo lutownicze w osi złącza, pod kątem $45^{\circ}$ w stosunku do powierzchni łączonych blach, rysunek 1 .

Do wykonania złączy zakładkowych użyto blach o wymia-

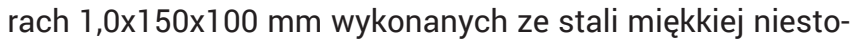
powej przeznaczonej do bezpośredniej obróbki plastycznej gatunku DC04+ZE75/75 (wg PN-EN 10152:2011) obustronnie elektrolitycznie pokrytych powłoką cynkową o grubości

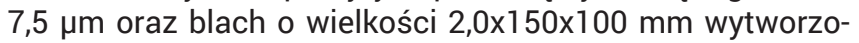
nych z aluminium gatunku 1050A (wg PN-EN 573-3:2014). Skład chemiczny oraz własności wytrzymałościowe materiałów lutospawanych przedstawiono w tablicy II i tablicy III.

Do prób lutospawania użyto proszek aluminium gatunku 1070A (wg normy PN-EN 573-3:2014) o granulacji $450 \mu \mathrm{m}$, tablica IV. Spoiwo o takim składzie chemicznym, przy odpowiednio oczyszczonej powierzchni materiału rodzimego w obszarze łączenia, zapewnia doskonałą spawalność

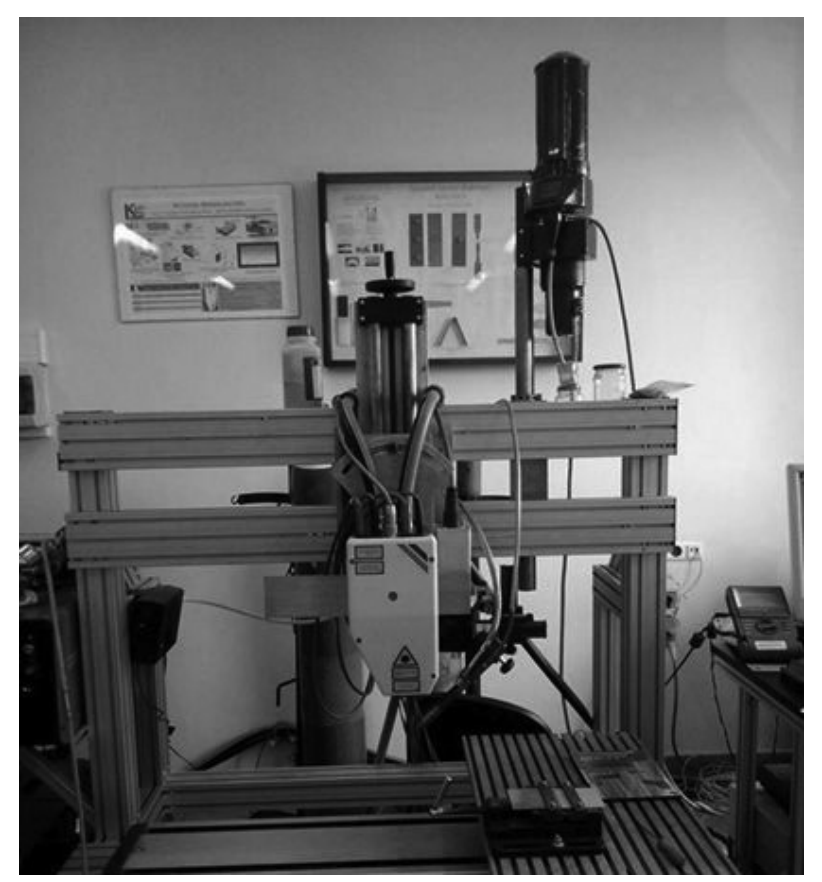

Rys. 1. Stanowisko badawcze do laserowego lutospawania z laserem diodowym dużej mocy Rofin DL020

Fig. 1. Experimental setup for laser braze welding equipped with a high power diode laser Rofin DL020 
Tablica IV. Skład chemiczny proszku aluminium gatunku 1070A (wg PN-EN 573-3:2014)

Table IV. Chemical composition of aluminium powder 1070A (according to PN-EN 573-3:2014)

\begin{tabular}{|c|c|c|c|c|c|c|c|}
\hline \multicolumn{1}{|c|}{ Zawartość składników stopowych [\%] } \\
\hline $\mathrm{Al}$ & $\mathrm{Si}$ & $\mathrm{Zn}$ & $\mathrm{Fe}$ & $\mathrm{Ti}$ & $\mathrm{Cu}$ & $\mathrm{Mn}$ & $\mathrm{Mg}$ \\
\hline$>99,70$ & $>99,70$ & $<0,07$ & $<0,25$ & $<0,03$ & $<0,03$ & $<0,03$ & $<0,03$ \\
\hline
\end{tabular}

Tablica V. Skład chemiczny oraz własności topników użytych do lutospawania (wg. danych producenta Castolin-Eutectic) Table V. Chemical composition and properties of brazing flux used (according to Castolin-Eutectic)

\begin{tabular}{|c|c|c|c|}
\hline Nazwa handlowa topnika & $\begin{array}{c}\text { Zakres temperatury } \\
\left.\text { aktywności topnika [ }{ }^{\circ} \mathrm{C}\right]\end{array}$ & Substancja & Pozostałość topnika \\
\hline EutecTor Flux 190 & $500 \div 700$ & Biały proszek & Koroduje \\
\hline Alu Flux 21 & $450 \div 650$ & Biały proszek & Koroduje \\
\hline
\end{tabular}

Tablica VI. Optymalne parametry wykonania różnoimiennych złączy zakładkowych w procesie lutospawania laserowego cienkich blach wytworzonych z aluminium gatunku 1050A oraz stali niestopowej gatunku DC04 obustronnie ocynkowanej elektrolitycznie z zastosowaniem spoiwa w postaci proszku aluminium gatunku 1070A

Table VI. Optimal conditions of laser braze welding of dissimilar lap joints between aluminum thin plate grade 1050A and double-sided electrogalvanized low-carbon sheet steel grade DC04 using aluminum powder 1070A as filler metal

\begin{tabular}{|c|c|c|c|}
\hline Nazwa handlowa topnika & $\begin{array}{c}\text { Zakres temperatury } \\
\left.\text { aktywności topnika [ }{ }^{\circ} \mathrm{C}\right]\end{array}$ & Substancja & Pozostałość topnika \\
\hline EutecTor Flux 190 & $500 \div 700$ & Biały proszek & Koroduje \\
\hline Alu Flux 21 & $450 \div 650$ & Biały proszek & Koroduje \\
\hline
\end{tabular}

i lutowność aluminium i jego stopów. Znajduje zastosowanie procesach łączenia technikami spawalniczymi elementów wykorzystywanych w przemyśle chemicznym, spożywczym, elektronice i budownictwie.

Przy wykonywaniu złączy zakładkowych lutospawanych wysokoenergetycznym laserem diodowym dużej mocy wraz ze spoiwem dodatkowo stosowano dwa rodzaje topników przeznaczonych do lutowania metali lekkich, tablica V. Topniki miały na celu poprawę zwilżania powierzchni łączonych blach. Ze względu na silnie aktywny charakter odziaływania używanych topników, bezpośrednio po procesie lutospawania konieczne było usunięcie ich pozostałości z powierzchni lutospoiny i połączonych blach.

Blachy aluminiowe $\mathrm{w}$ obszarze poddanym lutospawaniu zostały przygotowane poprzez delikatne zaokrąglenie krawędzi i oczyszczenie powierzchni papierem ściernym do połysku metalicznego, natomiast blachy stalowe odtłuszczano alkoholem etanolowym. Przeznaczone do łączenia zakładkowego elementy pozycjonowano względem siebie na stole wyposażonym w oprzyrządowanie mocujące, składające się z klamer usztywniających blachy. Każdorazowo blachę aluminiową nakładano na blachę stalową ustalając zakładkę wynoszącą $20 \mathrm{~mm}$.

Przed przystąpieniem do wykonania próbnych złączy zakładkowych, na podstawie wstępnych prób spawalniczych dobrano parametry procesu lutospawania laserowego wytypowanych blach z zastosowaniem materiału dodatkowego. Ustalono optymalną moc wiązki lasera diodowego wynoszącą: 1,4 kW. Ogniskową wiązki lasera, mierzącą 0,8 mm, kierowano na krawędź blachy aluminiowej. Prędkość lutospawania wynosiła $0,2 \mathrm{~m} / \mathrm{min}$, a do ochrony obszaru lutospawanego użyto argonu 5.0, którego natężenie przepływu wynosiło $2,5 \mathrm{dm}^{3} / \mathrm{min}$. Prędkość podawania proszku aluminiowego, zapewniająca odpowiednie formowanie lutospoiny, wyniosła $1,0 \mathrm{~g} / \mathrm{min}$. Wszystkie dobrane parametry zestawiono w tablicy VI.

Próby lutospawania laserem diodowym cienkiej blachy aluminiowej z blachą ze stali niestopowej obustronnie ocynkowaną elektrolitycznie przeprowadzono dla następujących przypadków:

- z zastosowaniem wyłącznie materiału dodatkowego w postaci proszku aluminium gatunku 1070A;

- z zastosowaniem materiału dodatkowego w postaci proszku aluminium gatunku 1070A wraz z topnikiem EutecTor Flux 190 rozpuszczonym w 96\% alkoholu etylowym;

- z zastosowaniem materiału dodatkowego w postaci proszku aluminium gatunku 1070A wraz z topnikiem Alu Flux 21 rozpuszczonym w 96\% alkoholu etylowym.

Ocena stabilności przebiegu procesu lutospawania laserowego blach aluminiowych ze stalowymi oraz badania wizualne otrzymanych lutospoin wykazały że:

- w trakcie wykonywania złącza zakładkowego z użyciem materiału dodatkowego w postaci proszku aluminium, bez topnika, procesu lutospawania przebiegał prawidłowo i odznaczał się dobrą rozpływnością stopiwa, w wyniku czego, uzyskano lutospoinę o metalicznym połysku wyróżniającą się licem o poprawnym kształcie i gładkiej powierzchni. Z obu stron złącza zakładkowego, w obszarze oddziaływania źródła ciepła, nie stwierdzono nadtopienia ani też odparowania warstwy ochronnej cynku z powierzchni blachy stalowej, rysunek 2 a) i 2 b);

- podczas wytwarzania złącza zakładkowego z wykorzystaniem spoiwa w postaci proszku aluminium i topnika lutowniczego EutecTor Flux 190 proces stapiania spoiwa spawalniczego przebiegał stabilnie i bez rozprysku. Stwierdzono jedynie nieznaczną wklęsłość lica przy akceptowalnej zmianie szerokości lutospoiny. $\mathrm{Na}$ powierzchni blachy stalowej od strony lica, jak i grani lutospoiny nie zauważono wyraźnego uszkodzenia warstwy ochronnej cynku. Zaobserwowano natomiast zjawisko w postaci ciemnego nalotu tworzącego się na czystej powierzchni blachy ocynkowanej, rysunek 2 c) i rys. 2 d);

- proceslaserowegoformowanialutospoinywzłączuzakładkowym z użyciem materiałów dodatkowych obejmujących proszek aluminium i topnik lutowniczy Alu Flux 21 przebiegał bez zakłóceń. Nie zidentyfikowano niezgodności 
kształtu i wymiarów lutospoiny. Stwierdzono za to, intensywny ciemny nalot, powstający po obu stronach złącza, na powierzchni lutospoiny oraz blachy aluminiowej i stalowej. Od spodu złącza zakładkowego na ocynkowanej blasze stalowej, w miejscu absorbcji wiązki promieniowania laserowego zauważono wyraźnie nadtopienie warstwy cynku, jednakże powłoka ochronna nadal silnie przylegała do powierzchni blachy, rysunek 2 e) i rysunek 2 f).
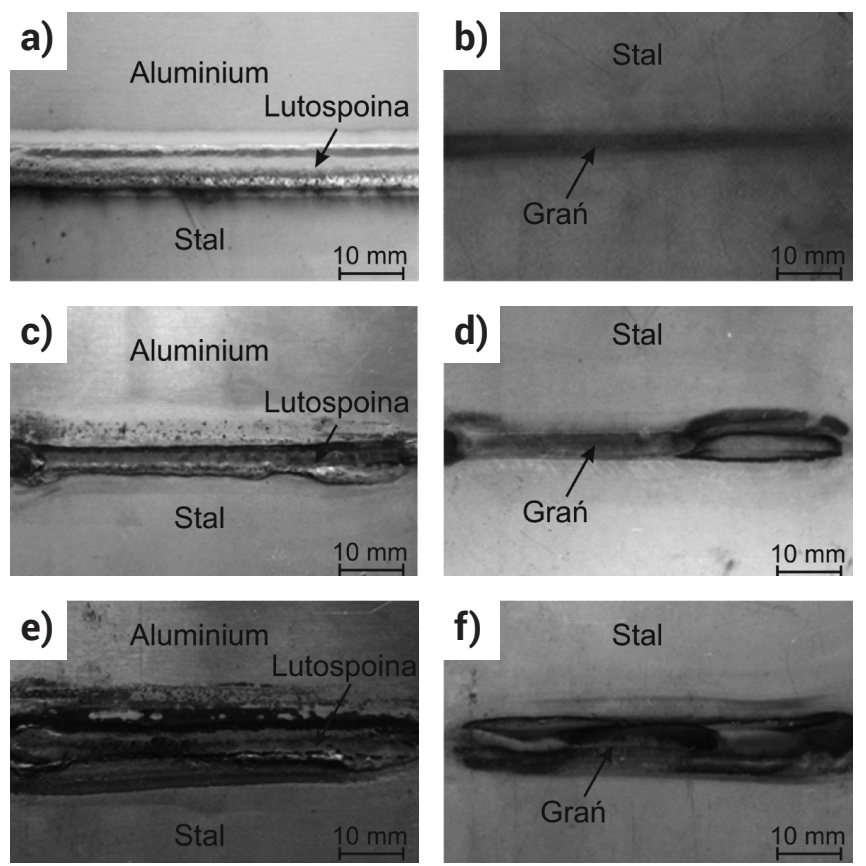

Rys. 2. Widok złączy zakładkowych uzyskanych w procesie lutospawania laserem diodowym cienkiej blachy aluminiowej gatunku 1050A z blachą ze stali niestopowej gatunku DC04 obustronnie ocynkowaną elektrolitycznie, z zastosowaniem materiału dodatkowego w postaci proszku aluminium gatunku 1070A: a), b) bez topnika; c), d) wraz z topnikiem EutecTor Flux 190; e), f) wraz z topnikiem Alu Flux 21

Fig. 2. A view of lap joints of aluminum thin plate grade $1050 \mathrm{~A}$ and double-sided electrogalvanized low-carbon sheet steel grade DC04 produced by laser braze welding using aluminum powder 1070A as filler metal: a), b) without brazing flux; c),d) with EutecTor Flux 190; e), f) with Alu Flux 21

Podczas procesu lutospawania nie zaobserwowano odkształceń spawalniczych łączonych blach. W każdym przypadku, występowało całkowite zwilżalnie materiałów łączonych przez stopiwo. Lutospoina w pełni wypełniała rowek spawalniczy, a warstwa ochronna cynku na powierzchni blachy stalowej z obu stron złącza zakładkowego nie została uszkodzona. W złączach nie występowały niezgodności typu pęknięcia zewnętrzne, przyklejenia lub brak wypełnienia rowka spawalniczego, które zaliczane są do wad niedopuszczalnych i niekwalifikujących złącza do eksploatacji.

Badania metalograficzne przeprowadzono w celu oceny poprawności wykonania złączy w skali makro i mikroskopowej. Przygotowanie próbek pobranych ze złącza różnoimiennego do obserwacji metalograficznych wymagało zastosowania złożonej procedury polerowania i trawienia. Przed badaniami makroskopowymi stal niestopową obustronnie ocynkowaną gatunku DC04 wytrawiono odczynnikiem Nital (3\% kwasu azotowego $\mathrm{w}$ alkoholu etylowym). Do trawienia lutospoiny i blachy aluminiowej użyto odczynnik Tuckera $(50 \mathrm{~g} \mathrm{Cu}, 400 \mathrm{ml}$ $\mathrm{HCl}, 300 \mathrm{ml} \mathrm{HNO}_{3}, 300 \mathrm{ml} \mathrm{H} \mathrm{O}$ ). Do badań mikrostruktury stal ocynkowaną poddano trawieniu Nitalem, natomiast części aluminiowe próbki trawiono roztworem 0,5 ml HF z 99,5 ml $\mathrm{H}_{2} \mathrm{O}$. Zdjęcia makrostruktury złączy wraz z obrazami mikrostruktury przedstawiającymi obszary materiału rodzimego, SWC, linie

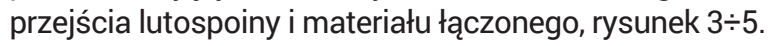
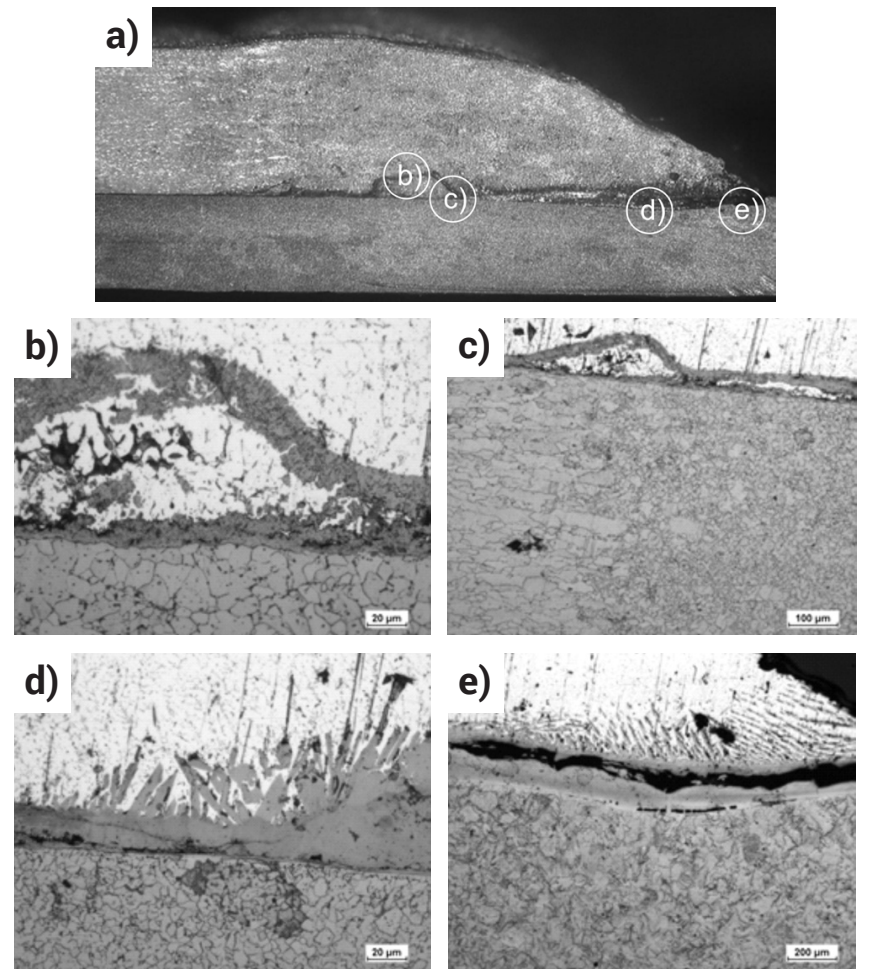

Rys. 3. Widok makrostruktury i mikrostruktury próbki pobranej ze złącza zakładkowego aluminium gatunku 1050A - ocynkowana stal niestopowa gatunku DC04, lutospawanego laserowo z zastosowaniem proszku aluminium gatunku 1070A bez użycia topnika (aluminium u góry, stal u dołu): a) makrostruktura złącza; b), c), d), e) mikrostruktura obszarów styku lutospoiny z ocynkowaną stalą niestopową

Fig. 3. Macro and microstructure of the lap joint of aluminum plate grade 1050A (upper plate) and galvanized low-carbon sheet steel grade DC04 (bottom plat) produced by laser braze welding using aluminum powder 1070A as filler metal, without brazing flux; a) macrostructure of the joint; b),c),d),e) micrographs taken from the contact area of the brazed seam to the galvanized steel sheet (regions marked in the macrograph)

$\mathrm{Na}$ podstawie zdjęć zgładów metalograficznych pobranych z różnoimiennych złączy zakładkowych blachy aluminiowej gatunku 1050A z obustronnie ocynkowaną blachą ze stali niestopowej gatunku DC04 lutospawanych laserem diodowym ze spoiwem w postaci proszku aluminiowego gatunku 1070A bez i z użyciem topnika lutowniczego zaobserwowano różnorodność połączenia w każdej z badanych próbek.

Strukturę aluminium gatunku 1050A stanowił roztwór stały a, a stali niestopowej gatunku DC04 drobne ziarna ferrytu ze śladowymi ilościami perlitu.

W złączu wykonanym bez użycia topnika, rysunek 3 , stwierdzono prawidłowy kształt przekroju poprzecznego lutospoiny, wolny od pęcherzy gazowych. Zidentyfikowano natomiast pasmowe wtrącenia w lutospoinie, znajdujące się tuż nad powierzchnią ocynkowanej blachy stalowej i biegnące równolegle do linii przejścia lutospoiny w materiał rodzimy, rysunek 3b) i 3c). Ponadto, odnotowano pęknięcie pomiędzy blachą ocynkowaną, a lutospoiną przedstawione na rysunku 3e). W blasze stalowej poniżej powłoki cynku zaobserwowano wąską SWC o strukturze powiększonych ziaren ferrytu z bainitem. Na rysunku 3d) przedstawiono niezidentyfikowane wtrącenia iglaste wnikające w lutospoinę.

W złączu wykonanym z użyciem proszku aluminium i topnika lutowniczego EutecTor Flux 190 zaobserwowano nieregularny kształt przekroju poprzecznego lutospoiny pozbawiony pęknięć, rysunek 4a). Linia przejścia między lutospoiną i blachą aluminiową charakteryzowała się dużą regularnością, praktycznie bez nadtopienie krawędzi materiału rodzimego, rysunek 4b). Prawa strona rysunek $4 b$ ) ukazuje strukturę $z$ dendrytycznymi wydzieleniami roztworu stałego aluminium a na tle drobnoziarnistej eutektyki, natomiast 

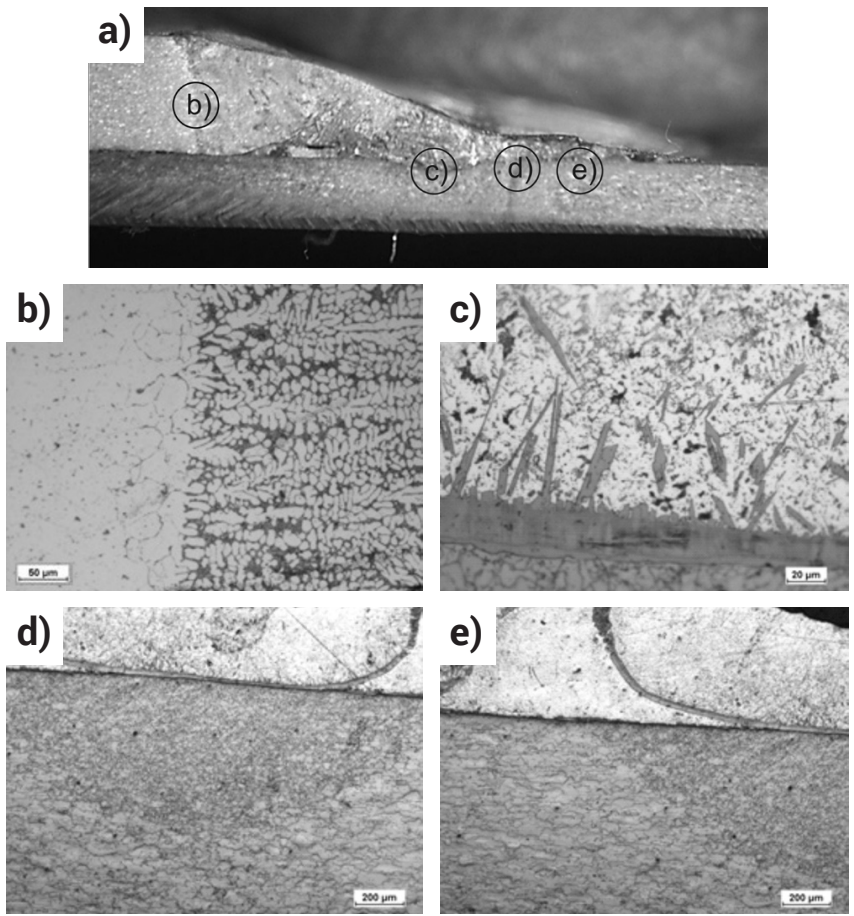

Rys. 4. Widok makrostruktury i mikrostruktury próbki pobranej ze złącza zakładkowego aluminium gatunku 1050A - ocynkowana stal niestopowa gatunku DC04 lutospawanego laserowo z zastosowaniem proszku aluminium gatunku 1070A i topnika lutowniczego EutecTor Flux 190 (aluminium u góry, stal u dołu): a) makrostruktura złącza; b) mikrostruktura obszaru styku lutospoiny z aluminium; c), d), e) mikrostruktura obszarów styku lutospoiny z ocynkowaną stalą niestopową

Fig. 4. Macro and microstructure of the lap joint of aluminum plate grade 1050A (upper plate) and galvanized low-carbon sheet steel grade DC04 (bottom plat) produced by laser braze welding using aluminum powder 1070A as filler metal and brazing flux EutecTor Flux 190; a) macrostructure of the joint; b) micrograph taken from the contact area of the brazed seam to the aluminium sheet; c),d),e) micrographs taken from the contact area of the brazed seam to the galvanized steel sheet

po lewej stronie zaobserwować można materiał rodzimy będący roztworem stałym aluminium a z pewną ilością perytektyk. Rysunek 4c) przedstawia podłużne, iglaste wtrącenia, których na poziomie zdjęć mikrostruktury złącza nie zidentyfikowano. W lutospoinie widoczne były również podłużne wtrącenia, jakby oderwane z powierzchni blachy ocynkowanej, rysunek 4d) i rysunek 4e). Zauważono również, że przy granicy międzyfazowej stal ocynkowana - materiał lutospoiny, powłoka cynku w pewnym stopniu rozpuszcza się w ciekłym stopiwie bez nadtopienia stalowego podłoża.

Złącze wykonane przy współudziale topnika lutowniczego Alu Flux 21 posiadało wszystkie charakterystyczne zmiany w strukturze występujące w wyżej omawianych połączeniach, rysunek 5. Jednakże, ilość pęknięć występujących w lutospoinie, przy powierzchni ocynkowanej blachy stalowej była znacznie większa.

Brak bardziej szczegółowej identyfikacji występujących w lutospoinie niezgodności, spowodował konieczność przeprowadzenia dokładniejszych badań powstałych wtrąceń oraz charakteru pęknięć z zastosowaniem skaningowego mikroskopu elektronowego (SEM).

$\mathrm{Na}$ obrazie SEM próbki pobranej ze złącza zakładkowego wykonanego z użyciem proszku aluminium i topnika lutowniczego EutecTor Flux 190, rysunek 6, przedstawiono obszar zewnętrznego naroża lutospoiny znajdujący się przy powierzchni ocynkowanej blachy stalowej. W analizowanym obszarze lutospoiny obok aluminium stwierdzono także wysoką zawartość cynku ok. $21 \%$ oraz podwyższone stężenie żelaza ok. 12\%. Powodem obecności metali w aluminiowej osnowie lutospoiny było stopienie powłoki cynkowej i częściowe nadtopienie materiału rodzimego.
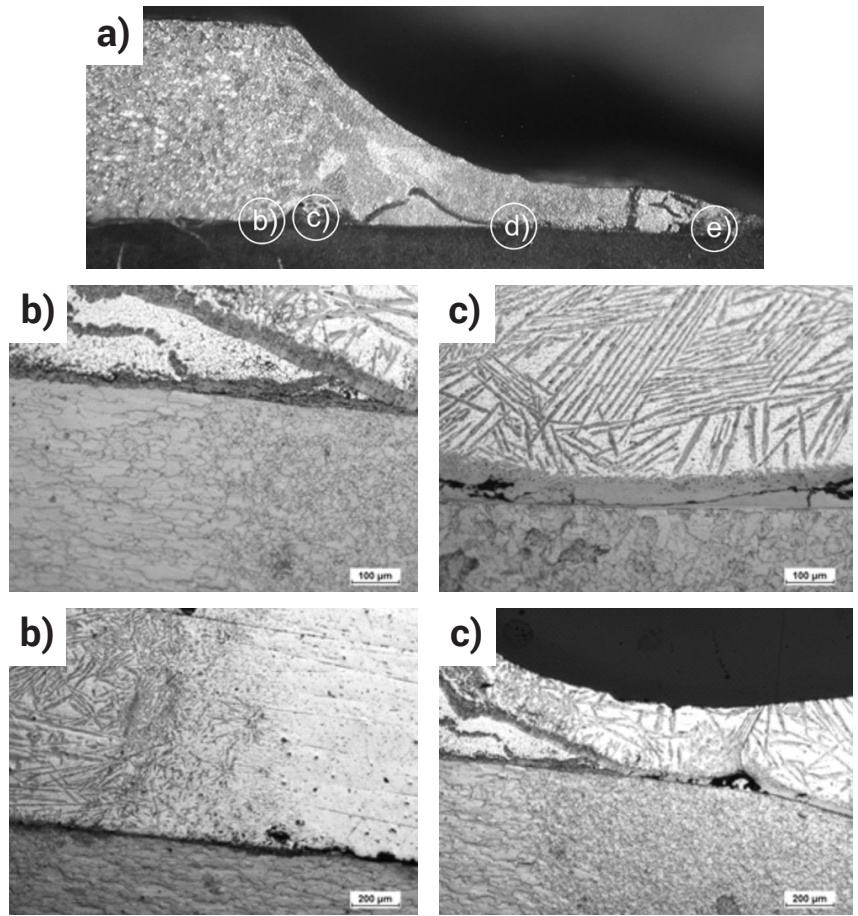

Rys. 5. Widok makrostruktury i mikrostruktury próbki pobranej ze złącza zakładkowego aluminium gatunku 1050A - ocynkowana stal niestopowa gatunku DC04 lutospawanego laserowo z zastosowaniem proszku aluminium gatunku 1070A i topnika lutowniczego Alu Flux 21 (aluminium u góry, stal u dołu): a) makrostruktura złącza; b) mikrostruktura obszaru styku lutospoiny z ocynkowaną stalą niestopową i aluminium; c), d), e) mikrostruktura obszarów styku lutospoiny z ocynkowaną stalą niestopową

Fig. 5. Macro and microstructure of the lap joint of aluminum plate grade 1050A (upper plate) and galvanized low-carbon sheet steel grade DC04 (bottom plat) produced by laser braze welding using aluminum powder 1070A as filler metal and brazing flux Alu Flux 21; a) macrostructure of the joint; b) micrograph taken from the contact area of the brazed seam between the galvanized steel and aluminium sheet; c),d),e) micrographs taken from the contact area of the brazed seam to the galvanized steel sheet
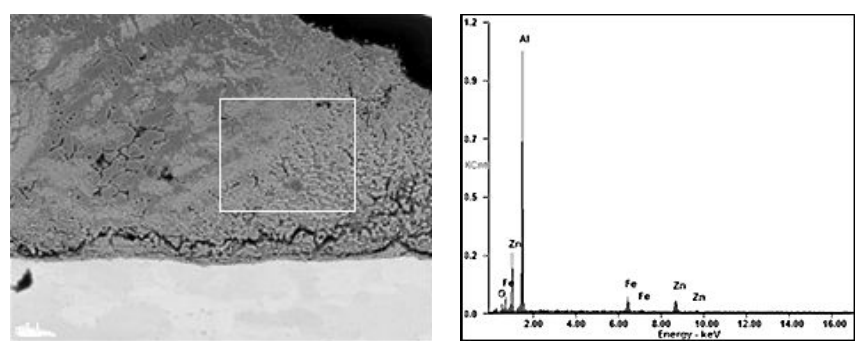

Rys. 6. Obraz SEM złącza zakładkowego aluminium gatunku 1050A - ocynkowana stal niestopowa gatunku DC04 lutospawanego laserowo proszkiem aluminiowym gatunku 1070A z użyciem topnika lutowniczego EutecTor Flux 190 (pow. 850x) oraz mikroanaliza składu chemicznego w obszarze pomiaru znajdującym się w lutospoinie przy powierzchni blachy stalowej

Fig. 6. SEM image of the lap joint of aluminum plate grade 1050A and galvanized low-carbon sheet steel grade DCO4 produced by laser braze welding using aluminum powder 1070A as filler metal and brazing flux EutecTor Flux 190 (magnification 850x) and EDS microanalysis taken form region in the brazed seam adjacent to the galvanized steel sheet

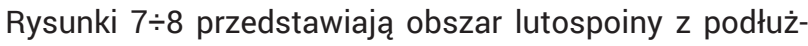
nymi wtrąceniami usytuowanymi nad powierzchnią blachy stalowej, rysunek 4 d) i e). We wszystkich analizowanych punktach stwierdzono obecność żelaza mieszczącą się w przedziale od $35 \%$ do $43 \%$. Obraz SEM przedstawiony na rysunek 9 ukazuje obszar przejścia lutospoiny $\mathrm{w}$ materiał rodzimy - blachę aluminiową gatunku 1050A. Stanowił on 
w ok. $88 \%$ roztwór stały aluminium a, oraz pochodzące z nadtopionej ocynkowanej blachy stalowej, rozpuszczone
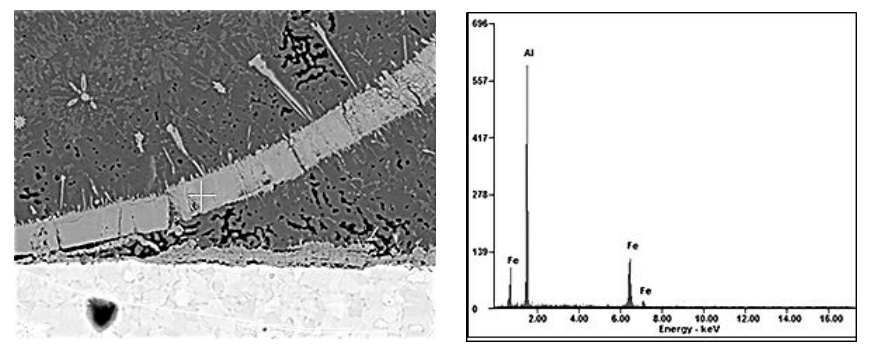

Rys. 7. Obraz SEM złącza zakładkowego aluminium gatunku 1050A - ocynkowana stal niestopowa gatunku DC04 lutospawanego laserowo proszkiem aluminiowym gatunku 1070A z użyciem topnika lutowniczego EutecTor Flux 190 (pow. 1000x) oraz mikroanaliza składu chemicznego $w$ punkcie pomiaru położonym na wtrąceniu znajdującym się w lutospoinie

Fig. 7. SEM image of the lap joint of aluminum plate grade 1050A and galvanized low-carbon sheet steel grade DC04 produced by laser braze welding using aluminum powder $1070 \mathrm{~A}$ as filler metal and brazing flux EutecTor Flux 190 (magnification 1000x) and EDS point analysis taken form a precipitation in the brazed seam w nim żelazo, magnez i cynk o zawartości wynoszącej odpowiednio $6 \%, 4 \%$ i $2 \%$
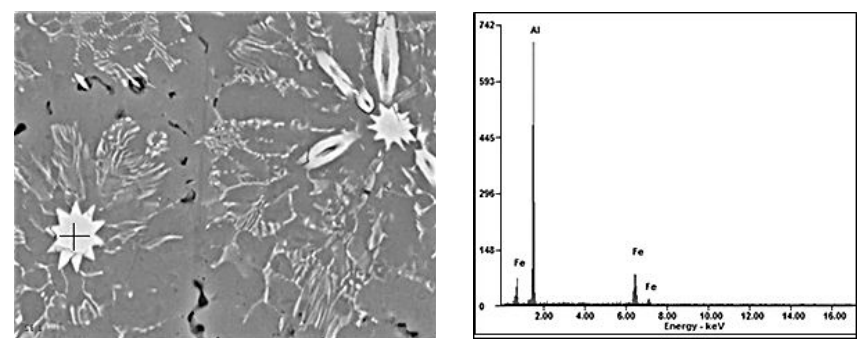

Rys. 8. Obraz SEM złącza zakładkowego aluminium gatunku 1050A - ocynkowana stal niestopowa gatunku DC04 lutospawanego laserowo proszkiem aluminiowym gatunku 1070A z użyciem topnika lutowniczego EutecTor Flux 190 (pow. 5000x) oraz mikroanaliza składu chemicznego w punkcie pomiaru położonym na wtrąceniu znajdującym się w lutospoinie

Fig. 8. SEM image of the lap joint of aluminum plate grade 1050A and galvanized low-carbon sheet steel grade DC04 produced by laser braze welding using aluminum powder 1070A as filler metal and brazing flux EutecTor Flux 190 (magnification 5000x) and EDS point analysis taken form a precipitation in the brazed seam
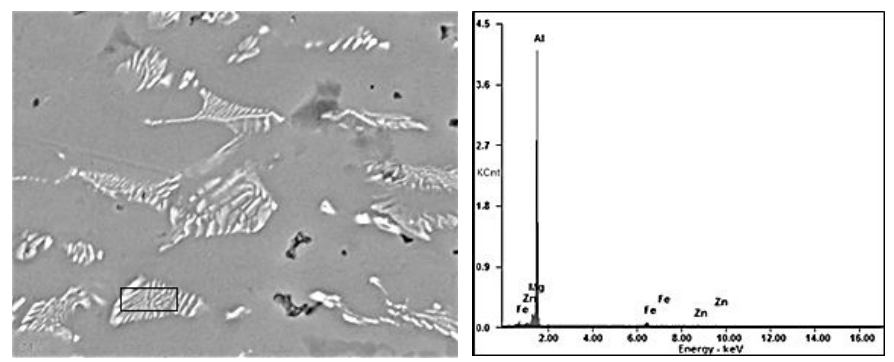

Rys. 9. Obraz SEM złącza zakładkowego aluminium gatunku 1050A - ocynkowana stal niestopowa gatunku DC04 lutospawanego laserowo proszkiem aluminiowym gatunku 1070A z użyciem topnika lutowniczego EutecTor Flux 190 (pow. 5000 x) oraz mikroanaliza składu chemicznego w obszarze pomiaru znajdującym się w lutospoinie przy powierzchni blachy aluminiowej

Fig. 9. SEM image of the lap joint of aluminum plate grade 1050A and galvanized low-carbon sheet steel grade DC04 produced by laser braze welding using aluminum powder $1070 \mathrm{~A}$ as filler metal and brazing flux EutecTor Flux 190 (magnification 5000x) and EDS microanalysis taken form region in the brazed seam adjacent to the aluminium sheet

\section{Podsumowanie}

Technologia lutospawania laserem diodowym dużej mocy materiałów różnoimiennych, w postaci cienkich blach wykonanych z aluminium gatunku 1050A i ocynkowanej stali niestopowej gatunku DC04 ułożonych na zakładkę, z użyciem spoiwa w postaci proszku aluminium gatunku 1070A charakteryzuje się dużą stabilnością przebiegu procesu i zapewnia formowanie lutospoin poprawnych pod względem kształtu i wymiarów. Wiązka promieniowania laserowego absorbowana przez stal niestopową nie powoduje uszkodzenia cynkowej powłoki ochronnej, w stopniu wpływającym na pogorszenie jej zabezpieczenia antykorozyjnego. Na podstawie badań wizualnych złączy nie jest możliwe zidentyfikowanie istotnych niezgodności spawalniczych. Jednakże, lutospoiny aluminiowe nie są wolne od niezgodności wewnętrznych w postaci wtrąceń i pęknięć. Pęknięcia w lutospoinach mają charakter pęknięć kruchych spowodowanych występowaniem kruchej fazy międzymetalicznej. Żelazo w znikomych ilościach rozpuszcza się w aluminium, dlatego tworzy, występujące w postaci wolnej, kruche fazy międzymetaliczne np. $\mathrm{Fe}_{3}$-Al lub Fe-Al, które wpływające na pogorszenie własności plastycznych lutospoiny. Rozpuszczalność cynku w roztworze stałym aluminium a jest również niewielka, z tego względu należy przypuszczać, że większa jego ilość przechodzi do roztworu w postaci wtrąceń tlenkowych np. $\mathrm{ZnO}, \mathrm{Al}_{2} \mathrm{O}_{4} \mathrm{Zn}$ czy $\mathrm{Fe}_{2} \mathrm{O}_{4} \mathrm{Zn}$. Wykonanie złącza zakładkowego o akceptowalnym poziomie jakości w technologii lutospawania laserowego z materiałem dodatkowym w postaci proszku aluminium jest trudne i wymaga sterowania ilością ciepła wprowadzanego do złącza, w sposób nie powodujący nadtopienia blachy stalowej.

\section{Literatura}

[1] Gawrysiuk W.: Technologia lutospawania łukowego. Zalecenia technologiczne i przemysłowe przykłady zastosowania, Biuletyn Instytutu Spawalnictwa 3 (2005) 35-40.

[2] Różański M., Gawrysiuk W.: Lutospawanie MIG/MAG blach ocynkowanych i przykłady trudno spawalnych układów materiałowych, Przegląd Spawalnictwa 9 (2007) 7-12

[3] Gawrysiuk W., Pfeifer T., Winiowski A.: Charakterystyka Technologii lutospawania łukowego MIG/MAG, Przegląd Spawalnictwa 2-3 (2005) 17-20.

[4] Białucki P., Ambroziak A., Derlukiewicz W., Lange A., Bednarek T.: Wpływ lutospawania łukowego na właściwości złączy stali ocynkowanej ogniowo, Przegląd Spawalnictwa 9 (2013) 20-28
[5] Matusiak J., Czworonóg B., Pfeifer T.: Spawanie i lutospawanie niskoenergetycznymi metodami MIG/MAG przeznaczonymi do łączenia materiałów i elementów wrażliwych na ciepło, Biuletyn Instytutu Spawalnictwa 6 (2007) 41-46.

[6] Ogura T., Saito Y., Ueda K., Hirose A.: Evaluation of interfacial microstructures in dissimilar joints of aluminum alloys to steel using nanoindentation technique, Journal of Physics: Conference Series 165 (2009) 012016 , doi:10.1088/1742-6596/165/1/012016.

[7] De Dompablo M.: Nowe rozwiązania w technologii spawania ColdArc i forceArc, Przegląd Spawalnictwa 7-8 (2009) 12-17.

[8] Różański M.: Nowoczesne metody lutospawania, Przegląd Spawalnictwa 9 (2010) 24-28. 